\title{
Upaya Menghadapi Covid-19 Pada Orang Dengan Gangguan Jiwa Melalui Kader Kesehatan Jiwa
}

\author{
Eni Hidayati1, Desi Ariyana Rahayu', Titik Suerni'1, Putri Lusi Putri Lusi Ratnasari1, \\ Emiliya Widyawati ${ }^{1}$
}

1 Fakultas Ilmu Keperawatan dan Kesehatan, Universitas Muhammadiyah Semarang, Indonesia

\section{Informasi Artikel}

Riwayat Artikel:

- Submit 13 Mei 2021

- Diterima 8 Juni 2021

- Diterbitkan 10 Juni 2021

Kata kunci:

Covid-19; Kader; Sehat

Jiwa; ODGJ

\begin{abstract}
Abstrak
Gangguan jiwa merupakan penyakit psikologis pada manusia. Gangguan jiwa adalah gangguan pikiran, gangguan perasaan atau gangguan tingkah laku sehingga menimbulkan penderitaan dan terganggunya fungsi seharihari (fungsi pekerjaan dan fungsi sosial) dari orang tersebut. Pelaksanaan program pengabdian ini dengan menggunakan metode pendekatan mitra binaan yang dilibatkan secara aktif dalam setiap tahapan dan kegiatan pembinaan yang dilakukan melalui pemberian pendidikan kesehatan. Alat yang digunakan dalam kegiatan ini adalah materi tentang upaya menghadapi covid-19 pada orang dengan gangguan jiwa pada kader-kader kesehatan jiwa dengan laptop, hp, dan materi video. pendidikan kesehatan pada kader kesehatan jiwa menjadi semakin paham tentang pencegahan Covid-19 dengan orang gangguan jiwa pada kader kesehatan jiwa. Kader banyak yang bertanya dan menujukkan antusias pada kader dalam melihat video materinya.. menanamkan kepada kader kesehatan jiwa ini sangat penting dengan melihat sangat penting dalam kekuatan kader kesehatan jiwa di masyarakat. Penyuluhan tentang kiat menghadapi covid-19 pada orang gangguan jiwa (ODGJ) pada kader kesehatan di wilayah RW 3 kelurahan kedungmundu. Kegiatan pengabdian ini dapat terlaksana dengan baik dan sesuai rencana atas kerjasama semua pihak, terutama sasaran yang mengikuti kegiatan sampai selesai di WAG kader.
\end{abstract}

\section{PENDAHULUAN}

Dunia saat ini tengah waspada dengan penyebaran sebuah wabah yang dikenal dengan virus corona. Wabah ini merupakan jenis virus baru yang ditemukan pada tahun 2019 dan belum pernah diidentifikasi menyerang manusia sebelumnya (World Health Organization, 2020). Corona virus atau yang dikenal juga dengan sebutan COVID-19 dinyatakan sebagai suatu pandemi global oleh World Health
Organization (WHO) pada 30 Januari 2020 (Desky, 2021). Berdasarkan data terbaru yang dikutip dari Kompas.com menunjukkan bahwa per tanggal 10 Mei 2021 perkembangan virus COVID-19 di Dunia sudah mencapai 158.953.101 kasus, dengan jumlah meninggal dunia sebanyak 3.306.229 Jiwa dari sebanyak 222 negara termasuk Indonesia.

Gangguan jiwa merupakan penyimpangan dari keadaan ideal seseorang dari suatu

Corresponding author:

Eni Hidayati

eni.hidayati@unimus.ac.id

SALUTA: Jurnal Pengabdian Kepada Masyarakat, Vol 1 No 1, Juni 2021

DOI: https://doi.org/10.26714/sjpkm.v1i1.8680 
Kesehatan mental. Pemahaman tentang kondisi sakit jiwa dapat mempengaruhi sikap dari masyarakat, yang menjadikan keluarga penderita sering kali memperlakukan penderita gangguan jiwa secara tidak adil (Risna, 2019). akar permasalahan pada gangguan jiwa berasal dari tiga pokok, pertama pemahaman atau pengetahuan masyarakat yang kurang tentang gangguan jiwa, kedua adalah stigma tentang gangguan jiwa yang kurang berkembang di masyarakat dan tidak meratanya pelayanan Kesehatan mental. Respon dan pemahaman yang belum benar terhadap penderita gangguan jiwa dengan perilaku kekerasan di masyarakat atau di keluarga masih banyak ditemukan, padahal peran masyarakat sangat penting terhadap kesembuhan penderita gangguan jiwa dengan gangguan perilaku kekerasan (Yulianti \& Wijayanti, 2016).

Orang dengan gangguan jiwa ialah orang yang mengalami gangguan dalam pikiran, perasaan dan perilaku yang termanifestasi dalam bentuk sekumpulan gejala dan/atau perubahan perilaku yang bermakna serta dapat menimbulkan penderitaan dan hambatan dalam menjalankan fungsi sebagai manusia (Indonesia, 2018). Seseorang dikatakan memiliki jiwa yang sehat apabila ia mampu mengenal diri sendiri, bersikap positif terhadap diri sendiri, dan mampu bersosialisasi dengan baik serta ia merasa berhasil diterima oleh masyarakat. Salah satu alternative pemecahan masalah pada penurunan cakupan gangguan jiwa dan pendidikan kesehatan dalam penyuluhan kader dan ibu mengenai kiat-kiat dalam menghadapi covid-19 pada orang dengan gangguan jiwa. Kegiatan ini merupakan upaya untuk membantu program penanganan gangguan jiwa. sebagaimana yang dijelaskan sebelumnya (Hidayati \& Nurwanah, 2019).

Berdasarkan latar belakang yang diuraikan, gangguan jiwa merupakan penyakit psikologis pada manusia. Gangguan jiwa adalah gangguan pikiran, gangguan perasaan atau gangguan tingkah laku sehingga menimbulkan penderitaan dan terganggunya fungsi sehari-hari (fungsi pekerjaan dan fungsi sosial) dari orang tersebut. Gangguan pikiran meliputi pikiran yang berulang-ulang, pikiran tentang sakit dan penyakit yang berlebihan, pikiran tentang ketakutan yang tidak masuk akal (irasional), keyakinan yang tidak sesuai dengan realitas/kenyataan (curiga, merasa dikejar-kejar, merasa mau dibunuh, dan lain-lain), gangguan persepsi (mendengar suara bisikan atau melihat bayangan yang tidak ada objeknya) di masa pademi covid19.

Selain itu pemberian pendidikan kesehatan tentang upaya menghadapi covid-19 pada orang gangguan jiwa di wilayah Kelurahan Kedungmudu Kota Semarang. Pendidikan kesehatan tentang upaya pencegahan covid-19 pada orang gangguan jiwa melalui kader kesehatan jiwa diberikan kepada para kader kesehatan jiwa dalam proses pengembangan kognitif, sehingga jika diberikan pendidikan kesehatan, kader kesehatan jiwa akan memiliki pengetahuan tentang upaya pencegahan covid-19 bagi pasien gangguan jiwa.

\section{METODE}

Pelaksanaan program pengabdian ini dengan menggunakan metode pendekatan mitra binaan yang dilibatkan secara aktif dalam setiap tahapan dan kegiatan pembinaan yang dilakukan melalui pemberian pendidikan kesehatan. Alat yang digunakan dalam kegiatan ini adalah materi tentang upaya menghadapi covid-19 pada orang dengan gangguan jiwa pada kaderkader kesehatan jiwa dengan laptop, hp, dan materi vidio. Proses dalam pengabdian ini melalui:

\section{Tahap persiapan}

Sebelum pelaksanaan pengabdian dilaksanakan, koordinasi dengan pihak kelurahan dan para kader kesehatan jiwa di 
kelurahan Kedungmundu, Kota Semarang. Selain mengurus perijinan, kami juga menjelaskan tujuan dan prosedur pengabdian masyarakat yang akan dilakukan. Setelah mendapat ijin dari kelurahan kami menetapkan waktu dan media yang cocok dengan para kader kesehatan jiwa yaitu sepakat di awal pademi ini kami memberikan pendidikan kesehatan kepada kader kesehatan jiwa malelui grub whatsapp. Persiapan materi kami membuat video ppt dan di share di grub whatsapp dan dilanjutkan dengan diskusi tentang pencegahan covid-19 khususnya pada pasien gangguan jiwa (ODGJ) (Hidayati et al., 2015).

\section{Tahap pelaksanaan}

Pendekatan pelaksanaan kegiatan pengabdian masyarakat dilakukan dengan memberikan pendidikan kesehatan tentang upaya pencegahan covid-19 dengan orang gangguan jiwa pada kader kesehatan jiwa. Media grub Whatsapp digunakan karena masih terjadinya pademi Covid-19 sehinga perlu mematuhi protokol kesehatan dengan tidak banyak berkumpul di satu tempat. Narasumber memberikan materi (video ppt) tentang upaya pencegahan Covid-19 kepada kader kesehatan jiwa.

\section{Tahap evaluasi}

Tindakan evaluasi untuk mengetahui adakah kendala dalam melakukan evaluasi pelaksanaan pengabdian masyarakat ini. Apresiasi kepada para kader kesehatan jiwa karena antusias dalam melakukan kegiatan dan pertanyaan kepada narasumber selama pelaksanaan pengabdian ini.

\section{HASIL DAN PEMBAHASAN}

Pelaksanaan kegiatan ini dilaksanakan pada 5 April 2020, pukul 15.30-17.00 WIB. Program pengabdian masyarakat ini dilakukan melalui WAG. Kegiatan pengabdian disampaikan oleh dosen dan mahasiswa di lingkungan Universitas
Muhammadiyah Semarang. Kegiatan di ikuti oleh 14 kader kesehatan jiwa. Materi yang diberikan yaitu materi tentang upaya tentang pencengahan covid-19 dengan gangguan jiwa. Setelah materi dengan video PPT di bagikan ke grop Whatsapp.

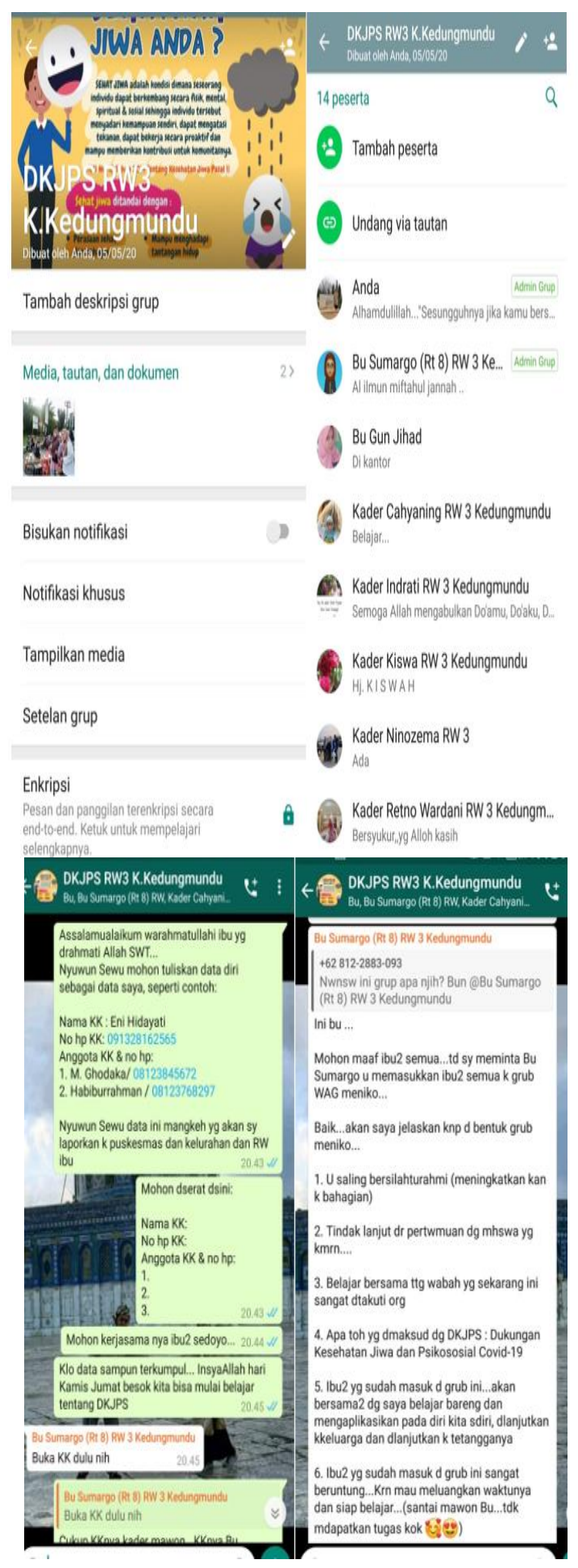

Gambar 1

Tampilan WhatsApp Group 
Hasil yang didapatkan dalam pendidikan kesehatan pada kader kesehatan jiwa menjadi semakin paham tentang pencegahan Covid-19 dengan orang gangguan jiwa pada kader kesehatan jiwa. Kader banyak yang bertanya dan menujukkan antusias pada kader dalam melihat video materinya.. menanamkan kepada kader kesehatan jiwa ini sangat penting dengan melihat sangat penting dalam kekuatan kader kesehatan jiwa di masyarakat.

Kader kesehatan jiwa mengungkapkan bahwa Covid-19 adalah wabah bagi kita semua. Pencegahan covid-19 pada pasien gangguan jiwa melalui beberapa dalam menjaga kesehatan mental kita dalam masa wabah covid-19 ini yaitu; batasi konsumsi berita dan selektif terhadap bacaan yang ada di media sosial. Hal tersebut menunjukan bahwa penyembuhan ODGJ masih menjadi masalah. Penderita yang dinyatakan sudah sembuh sering tidak siap untuk Kembali diterjunkan di keluarga dan masyarakat hal itu menjadikan penyebab penderita ODGJ mengalami kekambuhan Kembali (Wahyuningtyas, 2019).

Pandemi Covid-19 bukan hanya mengancam atau berpengaruh pada kesehatan fisik seseorang saja, akan tetapi juga pada kesehatan jiwa. Pembatasan Sosial Berskala Besar (PSBB) yang telah ditetapkan pemerintah ini juga memberikan dampak yang cukup besar bagi kalangan masyarakat Indonesia.

Pada akhir sesi kader kesehatan jiwa diberikan pertanyaan sedikit, kader menjawab pertanyaan dengan baik dan benar. Salah satu strategi perubahan perilaku adalah pemberian informasi kepada kader kesehatan jiwa tentang bagaimana cara penanganan covid-19 untuk pasien gangguan jiwa. Salah satu upaya pemberian informasi yang dilakukan dengan pendidikan kesehatan. Penyuluhan dengan metode ceramah dengan video ppt dapat meningkatkan pengetahuan kader kesehatan jiwa tentang upaya pencengahan covid untuk pasien gangguan jiwa.

Kekambuhan menurut Fikreyesus et al (2016) penderita yang tidak tinggal dengan keluarga memiliki risiko mengalami kekambuhan sebesar $72 \%$, penderita yang tidak patuh terhadap pengobatan memiliki risiko kekambuhan sebesar 69\%, penderita tidak mencari dukungan religious berisiko kambuh sebesar $45 \%$, serta sebesar $48 \%$ penderita tidak mendapat dukungan sosial akan berisiko mengalami kekambuhan (Fikreyesus et al, 2016)

Sikap masyarakat terhadap orang dengan gangguan jiwa dapat mempengaruhi kesembuhan atau penderitaan penderita gangguan jiwa, berdasarkan penelitian terdahulu menunjukan bahwa factor risiko sikap negatif terhadap orang dengan gangguan jiwa yaitu usia yang lebih tua, jenis kelamin laki-laki, etnis cina, Pendidikan yang rendah, dan status sosial ekonomi yang rendah (Nasriati, 2017). Hubungan antara pendidikan dengan Tingkat Pengetahuan Masyarakat Tentang Gangguan Jiwa (Palupi, 2019). Menunjukan bahwa tingkat pengetahuan masyarakat sebagian besar memiliki pengetahuan baik yaitu sebanyak 64 responden $(64,6 \%)$. Hal ini disebabkan karena responden mendapat informasi yang baik tentang orang dengan gangguan jiwa (Asriani et al., 2020).

\section{SIMPULAN}

Penyuluhan tentang Kiat menghadapi covid-19 pada orang gangguan jiwa (odgj) pada kader kesehatan di wilayah RW 3 kelurahan kedungmundu. Kegiatan pengabdian ini dapat terlaksana dengan baik dan sesuai rencana atas kerja sama semua pihak, terutama sasaran yang mengikuti kegiatan sampai selesai di WAG kader.

Kegiatan ini perlu dilakukan pada kader dan warga masyarakat lain, terutama warga yang di wilayah kena wabah covid-19 dan 
yang risiko penyakit gangguan jiwa, sehingga akan menambah pengetahuan tentang kia-kiat dalam menghadapi covid19 pada orang dengan gangguan jiwa dan kesehatan pada umumnya.

\section{UCAPAN TERIMA KASIH}

Penulis mengucapkan terimakasih kepada semua pihak yang telah membantu dalam persiapan dan pelaksanaan pengabdian kepada masyarakat ini.

\section{REFERENSI}

Asriani, Nauli, F. A., \& Karim, D. (2020). Sikap Masyarakat Pada Orang Dengan Gangguan Jiwa. Fakultas Keperawatan Universitas Riau.

Desky, D. F. (2021). Pengaruh Pandemi Covid-19 Terhadap Tingkat Stres Dan Pola Tidur Pada Mahasiswa Fakultas Kedokteran Universitas Sumatera Utara.

Fikreyesus, M., Soboka, M. dan Feyissa, G. T. (2016). Psychotic relapse and associated factors among patients attenting health services in southwest Ethiopia: a cross-sectional study', BMC Psychiatry. BMC Psychiatry. https://doi.org/10.1186/s12888-016-1076-2

Hidayati, E., Khoiriyah, \& Mubin, M. F. (2015). Pelatihan Siaga Sehat Jiwa Terhadap Pengetahuan Kader Di Rw 06 Dan Rw 07 Desa Rowosari Kecamatan Tembalang Kota Semarang. Jurnal Keperawatan Komunitas ., 3(No 1), 17-22.
Hidayati, E., \& Nurwanah, N. (2019). Tingkat Kecemasan Terhadap Prestasi Akademik Pengurus Ikatan Mahasiswa Muhammdiyah. Indonesian Journal for Health Sciences, 3(1), 13. https://doi.org/10.24269/ijhs.v3i1.1598

Indonesia, K. K. R. (2018). Riskesdas.

Nasriati, R. (2017). Stigma Dan Dukungan Keluarga Dalam Merawat Orang Dengan Gangguan Jiwa (ODGJ). MEDISAINS: Jurnal Ilmiah Ilmu - Ilmu Kesehatan, 15(1), 56-65.

Palupi, W. M. (2019). Evaluasi Media Promosi Kesehatan Jiwa.

Risna. (2019). Stigma Keluarga pada Penderita Gangguan Jiwa Family's Stigma on People with Mental Disorders. Stigma Keluarga Pada Penderita Gangguan Jiwa Family 's Stigma on People with Mental Disorders, 5(1), 28-37.

Wahyuningtyas, W. (2019). Peran Dukungan Keluarga terhadap Kekambuhan Gangguan Jiwa Rumah Singgah Dosaraso Kabupaten Kebumen. Stie Widya Wiwaha Yogyakarta.

World Health Organization. (2020). Coronavirus. Retrieved from World Health Organization: https://www.who.int/healthtopics/coronavirus . 19, 1-12.

Yulianti, T. S., \& Wijayanti, W. M. P. (2016). Hubungan Tingkat Pendidikan Dan Tingkat Pengetahuan Tentang Kesehatan Jiwa Dengan Sikap Masyarakat Terhadap Pasien Gangguan Jiwa Di Rw Xx Desa Duwet Kidul, Baturetno, Wonogiri. KOSALA : Jurnal Ilmu Kesehatan, 4(1), 1-12. https://doi.org/10.37831/jik.v4i1.79 